\title{
Non-Moses le Roux: Premises, promises and fulfilment in the work of J.H. le Roux
}

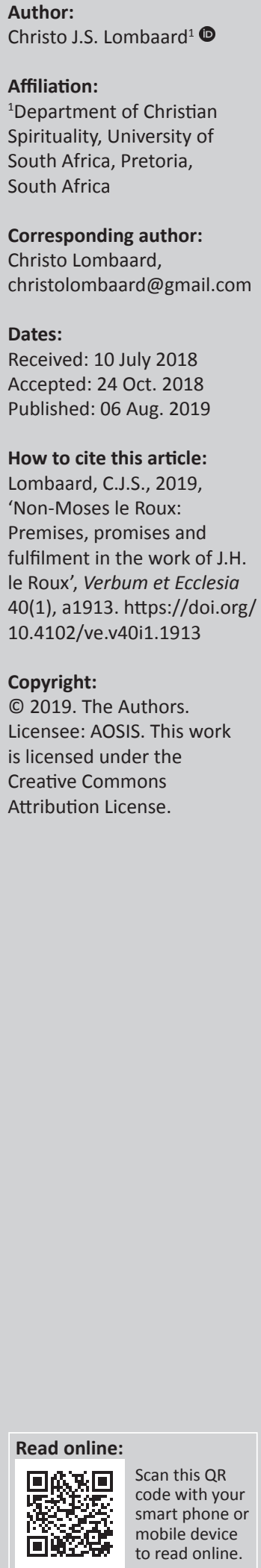

Would it be altogether out of place tongue-in-cheek to compare and contrast J.H. le Roux with Moses - given that both of them are inextricably linked to the literature of the Pentateuch? Both figures took leadership positions, although not aspiring to such roles: Moses, of the legendary exodus group, in the various texts we know and debate so well; and Le Roux through the following:

- his work as historical exegete

- his leadership of the Old Testament Society of South Africa

- his pioneering work since 2000 with the Pro Pent concept, which had influenced various other such specialist exegesis groups (respectively, on the Psalms, the Prophets, the Apocalyptic Literature, Song of Songs, Wisdom, in general, and on the Qumran texts)

- in leading his students and readers to promising new electronic lands by means of telematic teaching and the influential website www.teo.co.za.

Aspects of these roles of Le Roux are taken into review in this contribution.

Intradisciplinary and/or interdisciplinary implications: Old Testament scholarship and historiography.

Keywords: J.H. le Roux; South African Old Testament scholarship; historical exegesis.

\section{To be, or not to be, Moses}

Would it be altogether out of place to compare and contrast J.H. le Roux, one of the two figures being honoured at this seminar today, with Moses - given that both of them are inextricably linked to the literature of the Pentateuch? Le Roux, namely, is in some respects like Moses, and in some regards he is the opposite. We are for instance able to deduce a history of Moses from the Pentateuch (cf. recently, Assmann 2014 and more famously though exegetically less rigorously, Freud 1939), even though we know he did not write a single word of the introductory five books of the Bible; in fact, we are not quite sure that a Moses figure ever existed. In a phenomenologically roughly parallel way, we get to know the mind of Jurie le Roux most clearly through his writings on the Pentateuch (e.g. Le Roux 2000:592-606, 2001:234-244), of which we do know that he is indeed the author - shall we call him J? - whose existence we can verify without resorting to involved argumentation. Both figures took leadership positions, though not aspiring to such roles: Moses, of the legendary exodus group, in the various texts we know and debate so well; Le Roux, through:

- his work as historical exegete

- his leadership of the Old Testament Society of South Africa

- his pioneering work since 2000 with the Pro Pent concept (cf. Le Roux 2005:1-21), which had influenced various other such specialist exegesis groups (respectively on the Psalms, the Prophets, the Apocalyptic Literature, Song of Songs, Wisdom in general, and on the Qumran texts)

- in leading his students and readers to promising new electronic lands by means of telematic teaching (cf. Le Roux \& Lombaard 2002:12-15), an electronic newsletter (cf. Lombaard \& Rabe 2005:412-431) and the influential website www.teo.co.za (cf. Lombaard 2006:202-215).

Unlike Moses, Le Roux indeed experiences the positive fruit from these multifaceted journeys (Human 2006:801-819), even though there had been many problems en route, at times leading his great treks of scholarship along new routes. Le Roux can therefore be cast as a kind of Moses figure within South African Old Testament scholarship specifically and among theologians in general. However, the parallelism is not exact - hence, the title of this contribution: 'Non-Moses le Roux'. 
In the following, a brief analysis of the oeuvre le Roux will be presented. More will be left unsaid than will be said. This is partly so because the points made below are but one take on only one part of Le Roux's contributions as an intellectual. In addition, this analysis is limited because, as always in academic representation, here too - and only in this tonguein-cheek sense! - I do not have much time for Le Roux: the minutes are limited. As a former student of his, I ask his forgiveness for this, as I have asked his forgiveness for other miscarriages too. As Le Roux follows Augustine (Confessiones $\mathrm{XI}$ ) in the view that time does not exist in any definable way, brevity will be forgiven, however, as readily, I believe, as any misrepresentations I commit in what follows.

The attempted representations try to sketch primarily the role of premises in Le Roux's thinking (cf. Le Roux 1991: 277-292). Of the four leadership roles Le Roux had taken on, listed above, it is only the first that will receive proper attention here (cf., however, Human 2006:801-819); the others are featured in this contribution with passing mention only, unfairly so. Moreover, rather than a mere chronicling of Le Roux's work, I take my cue from his example (e.g. Le Roux 1993a), casting him in an interpretative mould, reading him deeply, as a singular occurrence, but not definitively. I try to sketch him 'thickly' (the slightly amusing term in academia for a rich and layered representation), as an intellectual, and I try to discern what makes him work, how his mind as an Old Testament scholar, and more, works, to the limited extent that I am able to discern as much.

This focus on Le Roux is, weaved, however, like the reeds of the metaphor employed by the predecessor of Le Roux to explain the layers of Pentateuchal texts (Van Zyl 1971:74 and his subsequent work; cf. Le Roux 1988a:84-96, 1993a:141152), with the theme of promise and fulfilment in the life of Le Roux. Le Roux had, as a young scholar, made no verbal promises about his future roles. It was clear that a thoroughly historical mindset, a primarily tradition-historical exegetical inclination (à la Von Rad), and a kind of biographical, sympathetic approach to the work of colleagues would characterise his writings. He had been, however, to many of his contemporaries an enigma, a mystery. Mister and Rev. Le Roux, rather, showed this promise non-verbally by completing two Doctorates, which was unusual at the time, namely in Church History (1976) and in Old Testament Science (1981); this, following on a Master's degree in Sociology (1971; cf. Le Roux 1985:80-90), and complemented by continuing studies in Philosophy. 'Taking to hand the work that presents itself' (Doen wat die hand vind om te doen) in a way characterises the trajectory of Le Roux's career, also as he relates it himself. This includes his appointments at the Universities of South Africa and Pretoria (respectively, 19711986 [cf. Le Roux 1987a:198-221] and 1987-2009 [cf. Le Roux 1988b:160-180, 2009:100-120]), complemented by his parttime but ever-pervasive ministerial work (1972-2010).

Le Roux's full involvement in the Old Testament society, in steering scholarship along fresh, specialist paths, and with technology (cf. Human 2006:801-819), displays a similarly gradual, thoughtful ${ }^{1}$ unfolding of life opportunities. Perhaps, there may be detected here an underlying sense of restful trust in the calling to be a theologian, the same as is often popularly imagined of Moses. Nevertheless, there is no doubt that the research and professional history of Le Roux has been influential. It has also turned out to be unique allowing me the derring-do here to paraphrase Deuteronomy 34:10 as 'there has not arisen in South Africa a professor like non-Moses'.

\section{Confluence and influence}

In a footnote in my 2009 dissertation, I had called Le Roux something he did not like then, and which he will like even less now: 'the at present most influential Old Testament scholar in South Africa' (Lombaard 2009:32 fn. 13; cf. Human 2006:803). That followed on an earlier description of the existential aspect to Le Roux's exegetical work, entitled 'Teks en mens' (Lombaard 2006a:912-925), which made the point that Le Roux does not write 'cold' theology, analysing at a distance the texts of the Bible and the scholarly works on these texts. Rather, Le Roux 'lives into' these texts. Veldsman (2013:1-7) characterised this historical orientation as 'spiritual empathy': Le Roux namely finds meaning in the words from afar (cf. Deist \& Vorster 1986) and in the kind of historical scholarship (Le Roux 1989:23-42, 1997:401-123) that is twice contextual: it tries to relate the ancient words to the context of the biblical world, and then these texts to modern life contexts (Le Roux 1995:1-30; cf. Deist 1995:37-48; De Villiers 2005:229-253). This is done in an involved yet critical manner (Human 2006:806) so that neither antiquity nor the present trumps the other attaining meaning. Cold detachment, through for instance logical positivism and methodological distancing, finds as little place with Le Roux as the sweet intimacies of pietism would offer. Rather, piety and scholarship combine in an intellectual, humane matrix that destroys neither, but rather nurtures both experienced theology and scholarly Bible engagement.

The wide divergence of the two worlds, ancient and modern, is therefore acknowledged for what it is, namely as something of a starting point or principled orientation. A bridge is then built, drawing intellectually on the philosophical hermeneutics of Gadamer (1975; cf. e.g. Le Roux 2002a:383-392) and Heidegger, with a strong awareness of the implications of the work on deconstruction by Derrida and others, and with great appreciation for the work of Thiselton on hermeneutics (cf. Thiselton 1980). However, it is most foundationally the French existentialist philosophers Camus and Satre who are drawn upon by Le Roux, in what may be described as an experiential way. This meant not as something which in any way involves lesser intellectuality, but requires more: something that is sensed deeply personally, with a kind of human-and-above-human resonance of meanings-and-meaningfulness.

1.This is not in the sense of planning, but in the sense of careful consideration once an opportunity is presented. 
The high esteem in which Le Roux holds the French existentialists is demonstrated in personalised historical mode by his retracing their footsteps in Paris and visiting their graves. This is nothing if not lived, empathetic spirituality (Veldsman 2013:1-7). Existentialism is thus not dead; to the contrary, the existentialist grasp at fleeting meaning in mere moments of life, in the face of the absolute senselessness of existence, is in itself a wordlessly eloquent hold onto the meaninglessness of life. The tenuousness of mad existence (cf. Foucault 1967) is something to be savoured most strongly in the sheer face of nothingness (cf. Kourie 2008:59-75). Such savour is no grasp at straws in desperation, but something more concrete, namely biblically resonant: living out of the pastoral insight already in Ecclesiastes 3:1-8 ('For everything there is a season, and a time for every matter under heaven', etc.) in its honest, accepting realism (cf. Scheffler 1993). Transitoriness-yet-transitiveness in a way explains such an existence, with probably the clearest parallel to this the cross events (kruisgebeure) at the heart of Christianity: that death brings life.

The latter is existential rather than cerebral logic. If such a characterisation of Le Roux holds true, it renders his scholarship decades after this sense of call to theology and ministry as, still, deeply felt discipleship. This is a kind of authentic fides quarens intellectum (Anselm of Canterbury 1078): taking the razor-sharp philosophical cutting edges of our times as seriously as they can be, while at the same time trusting in what cannot be seen, and finding ultimate rest therein. This is done in ways that defy detailed description most of what is of greatest worth cannot be captured in words. The latter is something which witch-hunters could never grasp, who seek heresy outside all but their own decided-upon terminologies, who trust most deeply in their language, thereby - paradoxically - denying the God who transcends language (Lombaard 2012:951 fn. 6). The more authentic disciples are those who follow their master narrative even in ways not realised.

\section{Textually speaking}

In the text-reader-context communicative chain of the exegetical process (cf. Lombaard 2014:205-225), therefore, no simplicities, which many would find comforting, are allowed for by Le Roux. His appreciation for the insight on 'der garstig breite Graben' as formulated by Lessing (1979 [1777]:13) on the chasm between ancient world and modern reader is based on his awareness of the insurmountable pastness of the past (Le Roux 2001:444-457; cf. Le Roux 1993b:35-63), which is foundational to his historical mindset. This awareness is matched by his appreciation of the complexities both of the text and of modern life situations. The kind of second naivete (in the language of Ricoeur 1967:350-352), indicated in the paragraph above, fully incorporates the intricacies of both ancient text and modern context that a first naivete often finds difficult to come to terms with. Apart from the exegetical intricacies with each distinct text (Deist 1988), the dissension among Bible passages is pointed out by
Le Roux (1987b:31-44, 1992), indicating the difficulties in the important task of employing such a multiverse Bible in making theological contributions to latter-day problems (Le Roux 1995:1-30). No easy answers can be found: (1) for today, (2) from the Bible and (3) through interpretation.

In fact, more often than not, it is the quality of the questioning rather than the strength of an answer that attracts Le Roux's attention.

Moreover, the all too easy practical distinction between exegesis and application is not acceptable either: the one always already implies the other. At most one can find actualisation of a text or tradition within the Old Testament or Bible itself, from which may be deduced subsequent reenactment, in some parallel way, in the modern world (cf. Ausloos 2013:1). Though he does not argue it, Le Roux also demonstrates an alternate way: deep intellectual engagement with the text of the Bible, the problematics of hermeneutics and the intricacies of the modern world. Such an engaging approach is not only open-mindedly analytical, but it also changes Le Roux's views and his life. He cannot but be drawn into the ancient worlds of the Bible he reads (the primary texts) and on which he reads (the research literature), and the world whence he reads (his philosophical, sociological and hermeneutical interests).

This was not always easy. Le Roux had found himself early in his Old Testament career among what may be termed similar to the caste of the untouchables in India - the unstructurables $^{2}$ of South African Bible scholarship. Le Roux was namely part of the minority of South African exegetes then who had found in the historical-critical approaches the most meaningful engagement with these texts. Some of the discussions can be traced in the published dialogues with W.S. Prinsloo and J.A. Loader, with Le Roux's A story of two ways (1993) which may be read as his most extensive 'position paper' on historical versus text-immanent approaches to the Old Testament texts. Le Roux remained always unapologetically historical in theological orientation, though he displays always empathetic appreciation for methods and conclusions that differed from his. Le Roux's historical inclination is as much for philosophical as for personal or existential reasons; the latter because he could not remain untouched by the texts. As scholars in the discipline of Spirituality Studies had come to acknowledge openly to themselves (Liebert 2002:30-49), but which is as valid of other academic disciplines too: researchers become existentially implicated in their subject. This is clearer in the work of Le Roux than is the case with perhaps any of his contemporaries. Objectivity, that is, taking a detached stance from his subject matter, had never been an ideal with Le Roux. In a certain sense, this may be formulated as follows: one becomes one with one's field of intellectual immersion. That has certainly been the case with the fields in which Le Roux immerses himself.

2.One of the quips during the 1980 s had been that particularly Afrikaans and hence Reformed exegesis had as its confessional stance sola structura. 


\section{Groundedness}

The single aspect that elicits the greatest respect from Le Roux in the work of others is thorough theoretical groundedness. Only through one's informed, formulated premises of interpretation can the promise that understanding holds be fulfilled. For Le Roux, no understanding can take place without theory (cf. e.g. Le Roux 2001:444-457); there is no such thing as approaching one's subject matter with a tabula rasa state of mind. Superficiality in scholarship entails foremost that one is unaware of the theoretical grounding to which readings and views are pinned. Therefore, his appreciation is for the work of, for example, Van Huyssteen (1987) (cf. also Vorster, Van Aarde \& Mouton 1988). Hence, also Le Roux's dispiritedness when in interdisciplinary theological work the Bible is 'drawn in' by other disciplines, namely by stringing together some seemingly supportive Bible passages in order to build 'a theology of' or 'a biblical view on' a certain matter - as if the Bible can be simply called upon to witness in favour of a certain topic. In such 'theologising', the theoretical embeddedness of every textual reading is hardly ever acknowledged, rendering interpretations that are at once shallow, theoretically mingled or mangled in ways unrealised by the exponent, and self-serving rather than critical. This stance by Le Roux cuts the other way too: his suspicions are equally raised when exegetes draw all too summarily on philosophers (usually, one philosopher) in order to enlighten or support an adopted interpretative stance. Without theory, and theory properly understood, as Le Roux frequently emphasises, one cannot practice science.

On the inverse side, though, Le Roux regards highly work that builds forth on a theory, including one of an author's own construction. This holds valid also when the subject matter is explored in an interdisciplinary (within theology) way: a thorough groundedness is required in the theoretical approach drawn on within the second discipline. Such primary theoretical embeddedness explains why, within Old Testament scholarship, Le Roux remains enamoured of the theology of Von Rad (1960, 1962), two decades (cf., e.g., Le Roux 2002b:1577-1592) after his second dissertation, which was on Von Rad's theory, had been completed (Le Roux 1981). Within New Testament scholarship, Le Roux's ongoing appreciation for the work on the historical Jesus published by Andries van Aarde (cf., e.g. Le Roux 2002c:77-99 on Van Aarde 2001) can be understood in the same way, as but one example. In each instance, a fully expounded theory underlies the exegetical work that follows. That same initial theory also enables the employment of the insights gained, also beyond the exegetical findings. Theory births knowledge as much as it carries insights further.

In cross-disciplinary work (across the boundaries of the traditional theological encyclopaedia), it is precisely these dual grounds of an own theoretically-founded approach to the Bible text along with a deep immersion in the theoretical groundwork of another field, that draws Le Roux's highest esteem. This can be seen in his continuing appreciation for scholars who work in this way, and who would become his long-standing and active, influential discussion partners. I refer, firstly, to Eckart Otto, who had developed a wholly new and highly complex historical-critical theory on the developmental history of the Pentateuch (e.g. Otto 1999), recouping W.M.L. de Wette's groundbreaking insight (1805) which took Deuteronomy as the central text of the Pentateuch and of much of Israel's faith development since the 7th century BCE (cf. Le Roux 2010:20-35). Yet, parallel to this, Otto had developed a foundational research trajectory on Max Weber, as a field of scholarship in own right (Otto 2005), and which had informed much of Otto's work on the composition history of the Pentateuch, as is evident from his new Deuteronomy commentary (Otto 2012a, 2012b, 2016a, 2016b). A second example here is the work of Scheffler, which has for a substantial part focused on the thematics of poverty, investigated as it traverses both the Old Testament and, from his dissertation already (Scheffler 1993), the New Testament. This specialisation by Scheffler, based on the clear theological (though he would at times during his career probaly prefer the term philosophical) supposition of care for the poor, has been complimented with a thorough specialisation on the psychological understanding of the Old Testament, grounded in the works of most particularly Jung, whose oeuvre Scheffler had studied extensively. A last example is the work of Le Roux's long-time colleague and friend, and sometime neighbour, the late Ferdinand Deist. Deist had combined his substantial work on Pentateuch theory (1976, with the imaginative title 'Mosaïek van Moses', published in translation in 1988 as Mosaic of Moses) with his philosophical work on heuristics (1976, influentially; cf. Deist \& Le Roux 1987; Le Roux 1992:3-19) and on hermeneutics (Deist 1994, foundationally). In all these three instances, Le Roux had been drawn to the maturity of theoretical reflection, which had, also in interdisciplinary fashion, informed the colleagues' scholarly exegesis. In these cases, the adage 'by your friends you shall be known' holds true: this is a foundational feature of Le Roux's own intellectual constitution.

The latter also explains Le Roux's approach as a historiographer of South African Old Testament scholarship (see most notably again Le Roux 1993a). Based on his philosophy of history, Le Roux reads deeply and sympathetically into the various scholars' work while analysing them; that is - borne from philosophy of history while telling his story about them. All are cast within the two theoretical schools that had come to characterise South African Bible scholarship since the rise to prominence of structural analysis. In this same appreciative style, Le Roux had analysed the work of international colleagues, expressing, for instance, his appreciation for the sociological approach in the influential work by Gottwald (1985; cf. Le Roux 1985:80-90) and for the history of religions approach by Albertz (1992, cf., e.g. Le Roux 1996:610-622). 


\section{Et cetera, et cetera, et cetera}

'Et cetera, et cetera, et cetera' is one of Jurie le Roux's favourite expressions. The reason is: there is always more to say; further implications; much to think through.

This is no less true while discussing the work of Le Roux himself. What has been done here, above, is a mere skeleton sketch, and only partial at that, to which much must be added. The depth perspectives which I had tried to convey, however, are as follows: that there is an existential confluence to be detected between Le Roux and his subject, in that he is influenced by the primary and secondary texts to which he devotes his studious energies. This has been influential in some circles; misunderstood in others. Then, there is the importance of premise, of philosophical and theoretical grounding, in Le Roux's intellectual make-up, both in primary and, where applicable, secondary fields of specialisation. This is evident is his own work, in the colleagues who become his discussion partners, and in the publications he receives most foundationally. For me, it has been a privilege to be one of the people following such a non-Moses.

\section{Acknowledgements Competing interests}

The author declares that he has no financial or personal relationships that may have inappropriately influenced him in writing this article.

\section{Authors' contributions}

C.J.S.L. was the sole author on this article.

\section{Ethical considerations}

This article followed all ethical standards for a research without direct contact with human or animal subjects.

\section{Funding}

This research received no specific grant from any funding agency in the public, commercial, or not-for-profit sectors.

\section{Data availability statement}

Data sharing is not applicable to this article as no new data were created or analysed in this study.

\section{Disclaimer}

The views and opinions expressed in this article are those of the author(s) and do not necessarily reflect the official policy or position of any affiliated agency of the authors.

\section{References}

Albertz, R., 1992, Religionsgeschicte Israels in alttestamentlicher Zeit, vol. 1 Vandenhoeck \& Ruprecht, Göttingen.

Assmann, J., 2014, From Akhenaten to Moses: Ancient Egypt and religious change, American University in Cairo Press, Cairo.
Ausloos, H., 2013, "Actualisation" and "re-enactment": Two categories in understanding the Old Testament', Verbum et Ecclesia 34(2), 1-6. https://doi. org/10.4102/ve.v34i2.746

Deist, F., 1976, Mosaïek van Moses. Pentateugnavorsing sedert die Reformasie, Tafelberg, Kaapstad.

Deist, F., 1988, Mosaic of Moses, NG Kerkboekhandel, Cape Town.

Deist, F., 1994, Ervaring, rede en metode in Skrifuitleg. 'n Wetenskapshistoriese ondersoek na Skrifuitleg in die Ned. Geref. Kerk 1840-1990, Raad vir Geesteswetenskaplike Navorsing, Pretoria.

Deist, F. \& Le Roux, J., 1987, Rewolusie en reïnterpretasie. Hoofstukke uit die geskiedenis van Israel, Tafelberg, Kaapstad.

Deist, F. \& Vorster, W. (eds.), 1986, Words from afar (The literature of the Old Testament, Volume 1), Tafelberg, Cape Town.

Deist, F.E., 1976, Historiese heuristiek, teologiese hermeneutiek en Skrifgesag, Universiteit van Port Elizabeth, Port Elizabeth.

Deist, F.E., 1988, Witnesses to the Old Testament (The literature of the Old Testament, Volume 5), NG Kerkboekhandel, Pretoria.

Deist, F.E., 1995, 'On "synchronic" and "diachronic": Wie es eigentlich gewesen', Journal of Northwest Semitic Languages 21(1), 37-48.

De Villiers, P., 2005, 'Methodology and hermeneutics in a challenging socio-political context: The first twenty five years of "The New Testament Society of South Africa" (1965-1990) - Part two', Neotestamentica 39(2), 229-253.

De Wette, W.M.L., 1805, Dissertatio critico-exegetica qua Deuteronomium a prioribus libris diversum, alius cujusdam recentioris auctoris opus esse monstratu, s.n., Jena.

Foucault, M., 1967, Madness and civilization: $A$ history of insanity in the age of reason, Tavistock, London.

Freud, S., 1939, Moses and monotheism, Hogarth Press and the Institute of Psychoanalysis, London.

Gadamer, H.G., 1975, Wahrheit und Methode: Grundzuge einer philosophischen Hermeneutik, Mohr, Tubingen.

Gottwald, N.K., 1985, The Hebrew Bible. A socio-literary introduction, Fortress Press, Philadelphia, PA.

Human, D., 2006, 'Jurie Hendrik le Roux - deernisvolle mens en veelsydige akademikus', Old Testament Essays 19(3) 801-819.

Kourie, C., 2008, 'Mysticism: A way of unknowing', in P.G.R. de Villiers, C.E.T. Kourie \& C. Lombaard (eds.), The spirit that empowers: Perspectives on spirituality (Acto Theologica Supplementum 11), pp. 59-75, University of the Free State Press, Bloemfontein.

Le Roux, J., 1985, 'Sociology and the Old Testament', Old Testament Essays 3, 80-90.

Le Roux, J., 1987a, 'The Unisa Department of Old Testament: A theological appraisal', Old Testament Essays 5, 198-221.

Le Roux, J., 1988a, 'Albertus van Zyl as Ou-Testamentikus', in W.S. Prinsloo \& W. Vosloo (eds.), In mensetaal oor God se Woord, pp. 84-96, Lux Verbi, Kaapstad.

Le Roux, J., 1988b, 'Die Departement Ou Testament (UP), ' $n$ halwe eeu', Skrif en Kerk 9(2), 160-180

Le Roux, J., 1989, 'Biblical and modern historiography', Old Testament Essays 3(1), 23-42.

Le Roux, J., 1991, 'Oor paradigmas en progressie in die teologie', Skrif en Kerk (12)2, 277-292. https://doi.org/10.4102/ve.v12i2.1040

Le Roux, J., 1992, 'Once again, methods: A taste of Deistian hermeneutics', in W. Wessels \& E. Scheffler (eds.), Old Testament science and reality. A mosaic for Deist, 3-19, Verba Vitae, Pretoria.

Le Roux, J., 1993b, 'The nature of historical understanding (or: hermeneutics and history)', Studia Historiae Ecclesiasticae 19(1), 35-63.

Le Roux, J., 2000, 'Die oue weier om te verdwyn', Skrif en Kerk 21(3), 592-606.

Le Roux, J., 2001, 'New theories on the Pentateuch', Ned. Geref. Teologiese Tydskrif 14(3), 234-244.

Le Roux, J., 2002a, 'Hans-Georg Gadamer en die Ou Testament', Verbum et Ecclesia 23(2), 383-392. https://doi.org/10.4102/ve.v23i2.1204

Le Roux, J., 2002b, 'Gerhard von Rad - 'n honderd jaar', Hervormde Teologiese Studies 58(4), 1577-1592. https://doi.org/10.4102/hts.v58i4.723

Le Roux, J., 2002c, 'Andries van Aarde se vaderlose Jesus', Hervormde Teologiese Studies 58(1), 77-99. https://doi.org/10.4102/hts.v58i1.548

Le Roux, J., 2005, 'Pro Pent. A project for the study of the Pentateuch in South Africa', in E. Otto \& J. le Roux (eds.), A critical study of the Pentateuch. An encounter between Europe and Africa (Altes Testament und Moderne, Band 20), pp. 1-21, LIT Verlag, Münster.

Le Roux, J., 2009, 'The story of a department', Verbum et Ecclesia 30(2), 100-120.

Le Roux, J., 2010, 'Eckart Otto', Ned. Geref. Teologiese Tydskrif 23(2), 20-35.

Le Roux, J. \& Lombaard, C., 2002, 'The Old Testament in a new medium: Graduate studies in the Old Testament via the Internet at the University of Pretoria', Bulletin for Old Testament Studies in Africa 13, 12-15.

Le Roux, J.H., 1971, 'n Godsdienssosioiogiese ontleding van Max Weber se stelling dat Protestantisme verantwoordelik is vir kapitalisme (ongepubliseerde MAverhandeling), Universiteit van Pretoria, Pretoria.

Le Roux, J.H., 1976, Die Paasbeskouing van Gaudentius van Brixia (ongepubliseerde DD-proefskrif), Universiteit van Suid-Afrika, Pretoria. 
Le Roux, J.H., 1981, Uittog en Sinai: ' $n$ uiteensetting en kritiese bespreking van Gerhard von Rad se beskouinge (ongepubliseerde DTh-proefskrif), Universiteit van Suid-Afrika, Pretoria.

Le Roux, J.H., 1987b, 'Two possible readings of Isaiah 61', in P.G.R. de Villiers (ed.), Liberation theology and the Bible, pp. 31-44, University of South Africa, Pretoria.

Le Roux, J.H., 1992, Whose side is God on? / Aan wie se kant is God?, CB Powell Bible Centre, University of South Africa, Pretoria.

Le Roux, J.H., 1993a, A story of two ways. Thirty years of Old Testament scholarship in South Africa (Old Testament Essays Supplement Number 2), Verba Vitae, Pretoria.

Le Roux, J.H., 1995, 'No theology, no relevance, no new South Africa', Old Testament Essays 2, 1-30.

Le Roux, J.H., 1996, " $n$ Nuwe godsdiensgeskiedenis van Israel', Ned. Geref. Teologiese Tydskrif 37(4), 610-622.

Le Roux, J.H., 1997, 'Our historical heritage', Old Testament Essays 10(3), 401-423.

Le Roux, J.H., 2001, 'No theory, no science (or: Abraham is only known through theory)', Old Testament Essays 14(3), 444-457.

Lessing, G.E., 1777, 'Über den Beweis des Geistes und der Kraft', in H.G. Göpfert (Hrsg.) 1979, Werke, Band VIII: Theologiekritische Schriften III, pp. 9-14, Philosophische Schriften, Hanser Verlag, München.

Liebert, E., 2002, 'The role of practice in the study of Christian Spirituality', Spiritus 2(1), 30-49. https://doi.org/10.1353/scs.2002.0011

Lombaard, C., 2006a, 'Teks en mens. JH le Roux se lees van die Bybel binne die konteks van hoofstroom-eksegese in Suid-Afrika', Old Testament Essays 19(3), 912-925.

Lombaard, C., 2006b, 'Afrikaans, reformed and internetted. Some outlines of current Afrikaans e-spiritualities', in S. Petrilli (ed.), White matters / II bianco in questione, pp. 202-215, Athanor, 17(10), Meltemi, Rome, Italy.

Lombaard, C., 2009, Isaac in the Old Testament. A new interpretation from Genesis 22, based on hermeneutical-methodological and exegetical investigation (DD dissertation), University of Pretoria, Pretoria.

Lombaard, C., 2012, 'Om die Skrif tot stilte te bring ... Gewaarwordinge oor Afrikaanse Bybelse spiritualiteit', Litnet Akademies (Godsdienswetenskappe) 9(3), 929-951.

Lombaard, C., 2014, 'Getting texts to talk. A critical analysis of attempts at eliciting contemporary messages from ancient holy books as exercises in religious communication', Ned. Geref. Teologiese Tydskrif 55(1), 205-225. https://doi. org/10.5952/55-1-2-522
Lombaard, C. \& Rabe, M., 2005, 'Die oudste boodskap via die nuutste massamedium: Evaluering van 'n e-pos dagstukkiediens', Verbum et Ecclesia 26(2), 412-431. https://doi.org/10.4102/ve.v26i2.233

Otto, E., 1999, Das Deuteronomium. Politische Theologie und Rechtsreform in Juda und Assyrien (BZAW 284), De Gruyter, Berlin.

Otto, E., 2005, Weber, Max: Die Wirtschaftsethik der Weltreligionen. Das Antike Judentum. Schriften und Reden 1911-1920 (Max Weber-Gesamtausgabe, Band [1/2],1), Mohr Siebeck, Tübingen.

Otto, E., 2012a, Deuteronomium 1-11; Erster Teilband: 1,1-4 (Herders Theologischer Kommentar zum Alten Testament), Herder Verlag, Freiburg.

Otto, E., 2012b, Deuteronomium 1-11; Zweiter Teilband: 4,44-11,32 (Herders Theologischer Kommentar zum Alten Testament), Herder Verlag, Freiburg.

Otto, E., 2016a, Deuteronomium 12-34; Erster Teilband: 12,1-23,15 (Herders Theologischer Kommentar zum Alten Testament), Herder Verlag, Freiburg.

Otto, E., 2016b, Deuteronomium 12-34; Zweiter Teilband: 23,16-34,12 (Herders Theologischer Kommentar zum Alten Testament), Herder Verlag, Freiburg.

Ricoeur, P., 1967, The symbolism of evil, Beacon Press, Boston, MA.

Scheffler, E., 1993, Suffering in Luke's gospel, Theologischer Verlag, Zürich.

Scheffler, E.H., 1993, Prediker se positiewe raad, Universiteit van Suid-Afrika, Pretoria. Thiselton, A.C., 1980, The two horizons, PaterNoster, Exeter.

Van Aarde, A., 2001, Fatherless in Galilee: Jesus as Child of God, Trinity Press International, Harrisburg.

Van Huyssteen, J.W., 1987, Teologie as kritiese geloofsverantwoording, Raad vir Geesteswetenskaplike Navorsing, Pretoria.

Van Zyl, A.H., 1971, 'n Inleiding in die eerste vyf boeke van die Bybel, N.G. Kerkboekhandel, Pretoria.

Veldsman, D.P., 2013, 'Diep snydende vrae, met antwoorde gebore uit weerloosheid: N.a.v. Jurie le Roux se spirituele empatie', Verbum et Ecclesia 34(2), 1-7. https:// doi.org/10.4102/ve.v34i2.786

Von Rad, G., 1960, Theologie des Alten Testaments (Band 11), Christian Kaiser Verlag, München.

Von Rad, G., 1962, Theologie des Alten Testaments (Band 1; 4. Auflage), Christian Kaiser Verlag, München.

Vorster, W.S., Van Aarde, A.G. \& Mouton, J., 1988, Paradigms and progress in theology, Human Sciences Research Council, Pretoria. 